\title{
Dapsone therapy for the acute inflammatory phase of ocular pemphigoid
}

\author{
Alasdair I Fern, Jeffrey L Jay, Hamish Young, Rona MacKie
}

Tennent Institute of Ophthalmology, Western Infirmary, Glasgow G11 6NT

A I Fern

J L Jay

University Department of Dermatology, Western Infirmary, Glasgow

H Young

R MacKie

Correspondence to:

Jeffrey L Jay.

Accepted for publication

1 August 1991

\begin{abstract}
Oral dapsone was used to treat five patients who presented in the acute inflammatory phase of ocular pemphigoid. The diagnosis was made clinically by identifying cicatricial changes which were in some cases difficult to find. In all cases it was the inflammatory rather than the cicatricial features which responded to treatment. An initial dose of $100 \mathrm{mg} / \mathrm{day}$ was effective without toxicity. When $150 \mathrm{mg} /$ day was used patients experienced side effects. A clinical response was obtained after 1-4 weeks and could be maintained on a dose of between $50 \mathrm{mg}$ on alternate days and $100 \mathrm{mg} /$ day. Therapy was withdrawn during remissions which lasted up to 32 weeks but all cases required continuing therapy which has remained effective. Immunopathological examination was carried out on two occasions in all cases and although positive on at least one occasion the results did not correlate with disease activity or treatment. The inflammatory phase of ocular pemphigoid should be added to the list of diseases responsive to dapsone.
\end{abstract}

Cicatricial pemphigoid is a disease of unknown aetiology which results in chronic progressive blistering and scarring of mucosal epithelium. The oral mucosa is most commonly affected with the conjunctiva involved in $75 \%$ of cases and the skin in $21-30 \% . .^{123}$ The eye changes are characterised by subepithelial fibrosis with symblepharon formation. There is also an acute inflam-

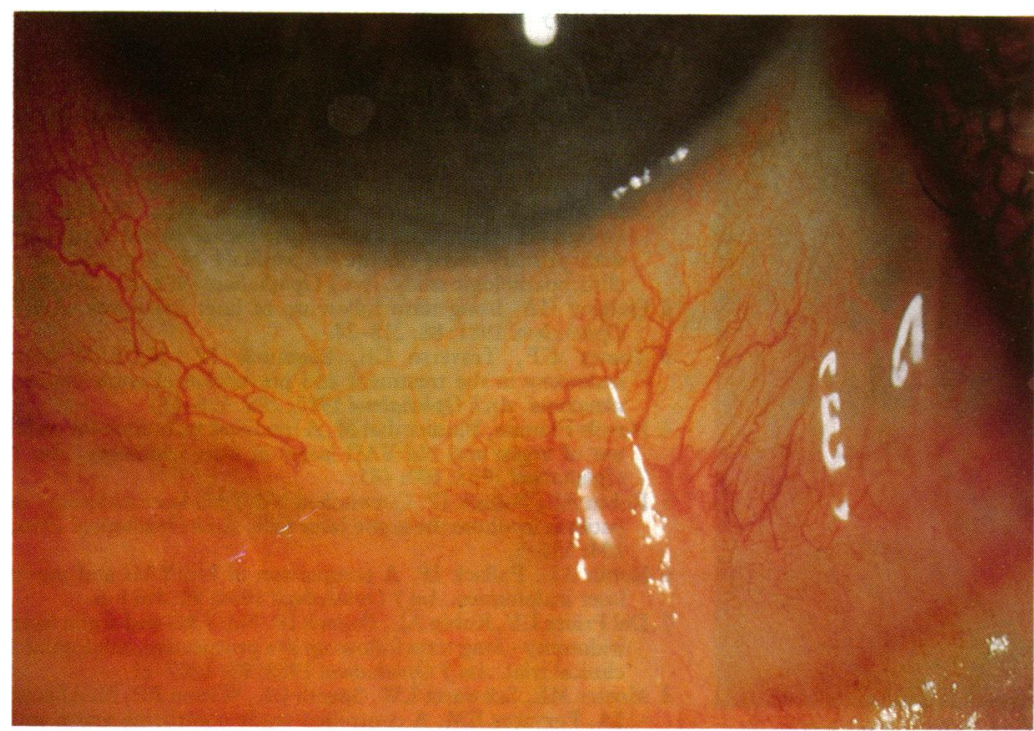

Figure 1 Early symblepharon in the lower fornix (case 4). This feature was of ten so mild as to be overlooked on initial examination. matory form of the disease with redness and swelling of the conjunctiva. ${ }^{4}$ In these cases of florid inflammation the cicatricial changes may be overlooked and the condition misdiagnosed.

Dapsone and other drugs of the sulfone group have been used for many years, particularly in dermatological practice to treat a variety of inflammatory conditions. Katz $\mathrm{K}^{5}$ lists 13 dapsone responsive conditions including dermatitis herpetiformis. Dermatological reports have suggested the drug may have an effect on a proportion of patients with cicatricial and bullous pemphigoid $^{678}$ but there is little information about its effect on ocular disease. We describe the value of dapsone in the treatment of the acute inflammatory features of ocular pemphigoid.

\section{Patients and methods}

We studied five consecutive patients between 1984-1990 who had ocular cicatricial pemphigoid in the acute inflammatory phase. None had a history of other causes of cicatricial conjunctivitis such as chronic infection, chemical trauma, or Stevens-Johnson syndrome.

Whether or not there was a history of skin lesions all patients were examined by a dermatologist.

The first two patients were commenced on dapsone $150 \mathrm{mg} /$ day but both developed haemolysis and one became cyanosed. Subsequent patients were therefore given a starting dose of $100 \mathrm{mg} /$ day in divided doses and the dose was reduced to the minimum required to maintain a clinical response. Where possible treatment was discontinued but if the condition relapsed the drug was re-introduced at the previous maintenance dose.

While taking the drug each patient's blood was examined regularly for evidence of haemolysis or anaemia.

Conjunctival and skin biopsies and serum samples for immunological assay were taken from each patient while they were without treatment and the disease was active and when the condition was in remission during treatment. Conjunctival biopsies were taken by a snip of upper bulbar conjunctiva elevated with forceps under topical anaesthesia with amethocaine $1 \%$ eye drops. Skin snip biopsy was taken from normal skin on the volar surface of the forearm after subcutaneous injection of $1 \%$ lignocaine with adrenaline. The specimens were frozen in liquid nitrogen and direct immunofluorescence staining performed with fluorescein-labelled antisera to human $\operatorname{IgG}, \operatorname{Ig} A, \operatorname{Ig} M$, and $C_{3}$. Indirect studies were performed for circulating antibodies to conjunctival epithelium and its basement membrane zone. 


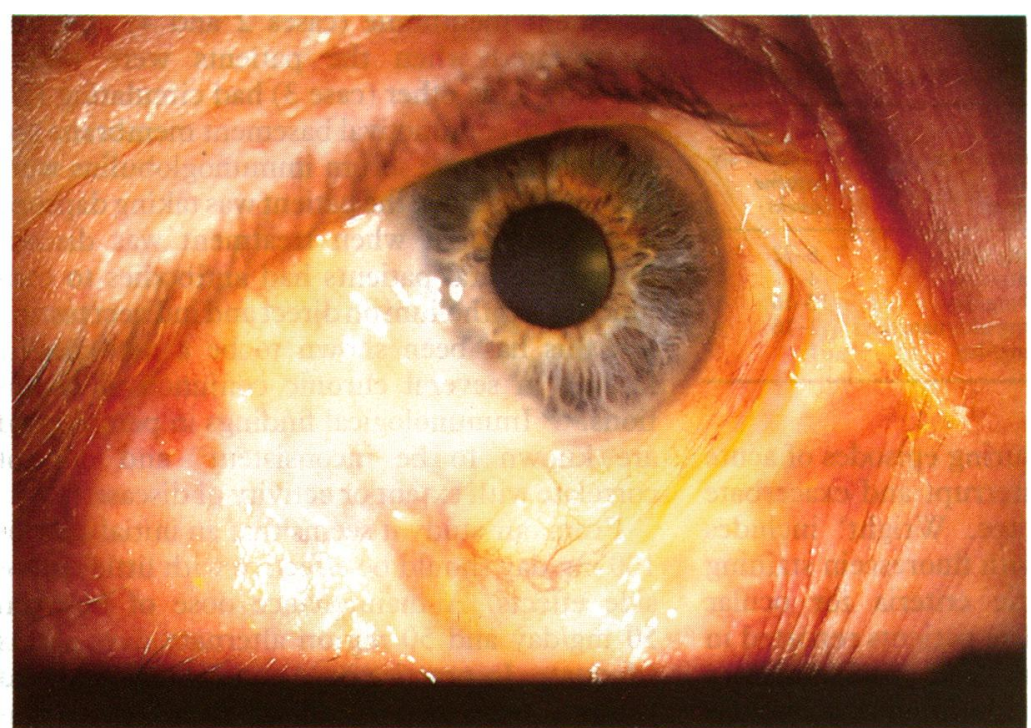

Figure 2 Advanced symblepharon with corneal pannus and scarring identified at presentation (case 2).

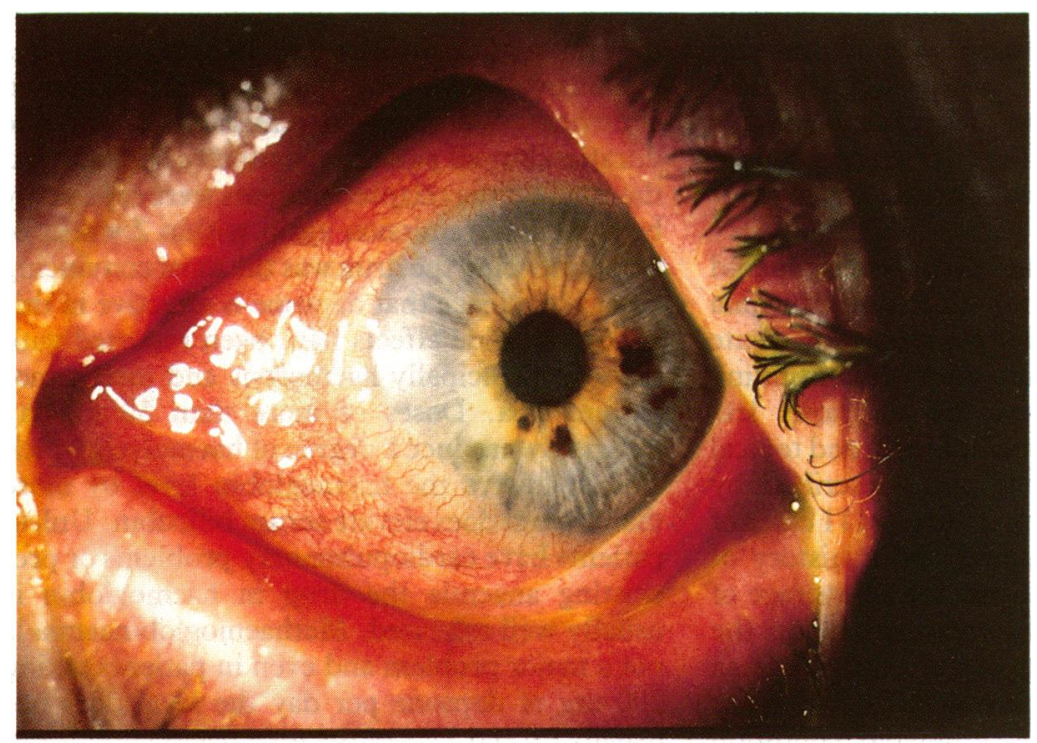

Figure 3 Inflamed conjunctiva prior to treatment (case 4).

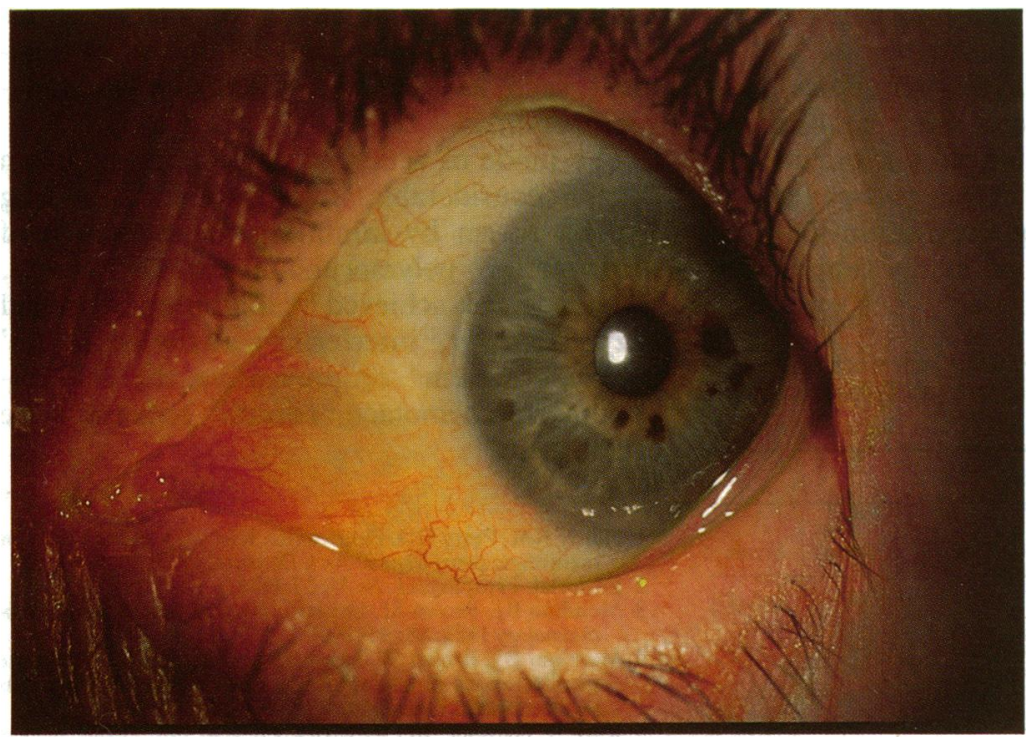

Figure 4 Remission of conjunctival inflammation 1 month after starting dapsone therapy. Same patient as Figure 3 (case 4).

\section{Results}

The mean age of the three male and two female patients was 60 years (range $40-72$ years). Three of the five cases presented with undiagnosed chronic conjunctivitis resistant to treatment. The diagnosis was eventually made clinically when previously overlooked subconjunctival fibrosis and symblepharon were identified (Fig 1). Selective involvement of the medial or lateral canthus was not present. In the other two patients cicatricial changes were obvious on presentation (Fig 2) allowing more rapid diagnosis.

Though there was cicatrisation in all cases the main presenting problem was chronic conjunctival inflammation with discomfort and pain. Figure 3 shows the inflammed conjunctiva of one patient and Figure 4 the same eye in remission on therapy. While both eyes were involved in every case there was often marked asymmetry. On stopping the drug the latent period before recurrence of the disease varied between patients and for individual patients on different occasions ranging from 1 week to 8 months.

Patient 1 had required treatment for 20 years for primary open angle glaucoma; formerly with topical adrenaline and pilocarpine latterly topical metipiranolol and oral dichlorphenamide. Topical glaucoma therapy was stopped when pemphigoid was diagnosed but the dichlorphenamide was continued.

The acute inflammatory element of ocular pemphigoid responded to the drug in all cases with a clinical response noted between 1-4 weeks after starting dapsone (Table 1). The response time varied for different patients but was consistent for each patient on every occasion the drug was recommenced. Some patients had initially received antibiotic and steroid drops but these were discontinued when the inflammation first responded to dapsone and could not account for the improvement in the patients' conjunctival appearance. Although the conjunctival inflammation was controlled by dapsone one case needed supplementary systemic steroid when severe corneal and scleral involvement occurred.

Toxic reactions to dapsone occurred at doses of $100 \mathrm{mg} /$ day or more. There was one case of mild jaundice and one of cyanosis and haemolysis. Both patients were able to continue effective long term therapy at reduced dose.

Dermatological examination identified only one patient with a skin disorder and this was described as psoriaform dermatitis after skin biopsy and is inconsistent with cicatricial pemphigoid. Two patients had oral signs suggestive of pemphigoid.

The immunofluorescent assay results are shown in Table 2 and categorised according to whether the patient was taking dapsone or not. Conjunctival biopsy did not stimulate ocular inflammation or progression of conjunctival fibrosis. No consistent pattern of immunological results can be detected.

\section{Discussion}

The cicatricial features of ocular pemphigoid are well recognised but the acute manifestations of the disease are not. Mondino ${ }^{+}$reports swollen 
Table 1 Patient details and response to dapsone showing minimum maintenance dose and length of asymptomatic remissions without treatment. All patients still require therapy

\begin{tabular}{|c|c|c|c|c|c|}
\hline Patient & $\begin{array}{l}\text { Age } \\
\text { (yrs) }\end{array}$ & $\operatorname{sex}$ & $\begin{array}{l}\text { Response } \\
\text { time } \\
\text { (weeks) }\end{array}$ & $\begin{array}{l}\text { Maintenance } \\
\text { dose of } \\
\text { dapsone }\end{array}$ & $\begin{array}{l}\text { Duration of } \\
\text { remission off } \\
\text { dapsone } \\
\text { (weeks) }\end{array}$ \\
\hline $\begin{array}{l}1 \\
2 \\
3 \\
4 \\
5\end{array}$ & $\begin{array}{l}67 \\
63 \\
43 \\
72 \\
59\end{array}$ & $\begin{array}{l}\mathrm{F} \\
\mathrm{M} \\
\mathrm{M} \\
\mathrm{F} \\
\mathrm{M}\end{array}$ & $\begin{array}{l}2 \\
2-4 \\
2 \\
3 \\
1\end{array}$ & $\begin{array}{l}50 \mathrm{mg} / \text { day } \\
50 \mathrm{mg} / \text { day } \\
100 \mathrm{mg} / \text { day } \\
50 \mathrm{mg} / \text { alternate days } \\
50 \mathrm{mg} / \text { day }\end{array}$ & $\begin{array}{l}6-32 \\
4 \\
10-16 \\
1-16 \\
1\end{array}$ \\
\hline
\end{tabular}

mounds of conjunctiva during episodes of acute disease activity which interrupt and exacerbate the conjunctival shrinkage. Wright' includes conjunctival ulceration with fluorescein staining in the clinical diagnostic criteria for ocular cicatricial pemphigoid. The patients reported in our paper illustrate the acute inflammatory features of conjunctival induration and vascular dilatation with chronic ocular irritation. It is these aspects that responded to dapsone therapy.

Although the condition is rare ${ }^{10}$ the diagnosis of ocular pemphigoid should be considered in any patient presenting with undiagnosed conjunctival inflammation. There is a condition with cicatricial conjunctivitis known as linear IgA disease which is responsive to dapsone. "None of our patients had any extraocular lesions consistent with linear IgA disease or dermatitis herpetiformis.

Case 1 may represent pseudo-pemphigoid initiated by 20 years of topical antiglaucoma therapy..$^{1214}$ However the persistence of acute conjunctival inflammation after discontinuing topical medication makes the diagnosis less likely. The association of pemphigoid and topical therapy for glaucoma has been described by Tauber et $a l^{15}$ who found that $26 \%$ of 111 cases of ocular cicatricial pemphigoid had a history of medical therapy for glaucoma for an average of 11 years. Nearly all had this treatment before the onset of pemphigoid suggesting that glaucoma medication may be a causative factor. Whether this is a separate 'pseudo-pemphigoid' condition or merely pemphigoid in which the usually idiopathic trigger factor has been identified it is known they are histologically and immunologically indistinguishable. ${ }^{16}{ }^{17}$ Both seem to respond equally to dapsone.

Cicatricial pemphigoid remains a clinical diagnosis. Immunological tests may confirm the diagnosis when positive but do not exclude the diagnosis when negative. Only two patients in our study showed the diagnostic finding of linear immunoglobulin deposition at the conjunctival

Table 2 Summary of immunofluorescent results. Tests were carried out both on and off treatment in every case. Although positive on at least one occasion in each case the pattern did not correlate with either disease activity or treatment

\begin{tabular}{|c|c|c|c|c|c|c|c|c|}
\hline \multirow[b]{2}{*}{ Patient } & \multicolumn{4}{|c|}{ On dapsone } & \multicolumn{4}{|c|}{ Off dapsone } \\
\hline & $\begin{array}{l}\text { Clinical } \\
\text { state }\end{array}$ & Conj & Skin & Serum & $\begin{array}{l}\text { Clinical } \\
\text { state }\end{array}$ & Conj & Skin & Serum \\
\hline $\begin{array}{l}1 \\
2 \\
3\end{array}$ & $\begin{array}{l}\text { Inactive } \\
\text { Inactive } \\
\text { Inactive }\end{array}$ & $\begin{array}{l}\text { ND } \\
\mathrm{ND} \\
\mathrm{IgA}(\mathrm{E})\end{array}$ & $\begin{array}{l}-v e \\
\text { ND } \\
-v e\end{array}$ & $\begin{array}{l}\operatorname{IgA}(C) \\
-v e \\
\operatorname{IgG}(B M) \text { and } \\
\quad \operatorname{IgA}(B M)\end{array}$ & $\begin{array}{l}\text { Inactive } \\
\text { Active } \\
\text { Inactive }\end{array}$ & $\begin{array}{l}\text { ND } \\
\text { IgA(L) } \\
- \text {-ve }\end{array}$ & $\begin{array}{l}\text { ND } \\
- \text { ve } \\
-v e\end{array}$ & $\begin{array}{l}\operatorname{IgA}(C) \\
-v e \\
-v e\end{array}$ \\
\hline $\begin{array}{l}4 \\
5\end{array}$ & $\begin{array}{l}\text { Inactive } \\
\text { Inactive }\end{array}$ & $\begin{array}{l}-\mathrm{ve} \\
\operatorname{IgA}(E)\end{array}$ & $\begin{array}{l}\text {-ve } \\
\text {-ve }\end{array}$ & $\begin{array}{l}\text {-ve } \\
\text { - ve }\end{array}$ & $\begin{array}{l}\text { Inactive } \\
\text { Active }\end{array}$ & $\begin{array}{l}\text { IgA }(L) \\
-v e\end{array}$ & $\begin{array}{l}\text {-ve } \\
\text {-ve }\end{array}$ & $\begin{array}{l}\text {-ve } \\
\text { IgG.(C) }\end{array}$ \\
\hline
\end{tabular}

$\mathrm{L}=$ linear; $\mathrm{E}=$ intraepithelial $\mathrm{C}=$ to conjunctiva; $\mathrm{BM}=$ to basement membrane; $\mathrm{ND}=$ not done. basement membrane (cases 2 and 4 ) and this disappeared when the patients were taking dapsone. One other (case 3) had circulating IgG and IgA to conjunctival basement membrane but paradoxically the serum immunoglobulins were only present when the patient was taking dapsone and disappeared when treatment was discontinued. Several patients had antibodies to conjunctival epithelium on direct and indirect testing but this has been shown to be a non-specific finding in several chronic conjunctival conditions. ${ }^{18} 19$ Immunological findings in pemphigoid are known to be inconsistent ${ }^{20}$ and do not correlate with extent or activity of disease..$^{21}$

From our study it seems that an initial dose of $100 \mathrm{mg} /$ day should be effective with little risk of side effects. A maintenance dose of between $50 \mathrm{mg} /$ day and $50 \mathrm{mg}$ on alternate days seems adequate. In practice once control was achieved patients were able to adjust their own maintenance dose. This varied with the severity of their symptoms and at all times they remained under medical supervision. Rogers et $\mathrm{al}^{7}$ recommend an initial low dose and a gradual increase over a 2 week period to the therapeutic level but they found the ocular features of pemphigoid less responsive to dapsone than mucosal ulceration elsewhere. We observed remissions of variable duration but all patients eventually relapsed and the fact that the relapsed patients were repeatedly brought into remission again within 2 weeks of recommencing the drug was the most convincing clinical evidence that dapsone is effective in this condition. Side effects have been reported with dapsone principally haemolysis and methaemoglobinaemia. Doses of more than $50 \mathrm{mg} /$ day invariably produce a degree of haemolysis which seldom lowers the haemoglobin level by more than $1 \mathrm{~g}$ but does elevate serum bilirubin. Unless patients have cardiopulmonary problems or preexisting anaemia the drop in haemoglobin is usually well tolerated. Methaemoglobinaemia is not a major problem and even in patients taking $200 \mathrm{mg}$ of dapsone per day the level does not usually exceed $12 \%$ of the total haemoglobin and is often less than $5 \% .^{5}$ This may give the patient a grey cyanosed appearance but is otherwise asymptomatic. Dapsone is relatively non-toxic and particularly in an elderly population seems safer to use than other possible means of treatment such as systemic steroids or immunosuppressants. ${ }^{22} 23$

The mode of action of dapsone is unknown despite considerable investigation. The drug appears to act by inhibiting the migration of neutrophilic polymorphonuclear leucocytes. Whether this is achieved by inhibiting lysosomal enzyme activity, ${ }^{24}$ interfering with the leucocytes' cytotoxic system ${ }^{25}$ or preventing the cell responding to chemotactic stimuli ${ }^{26}$ remains to be established.

1 Hardy KM, Perry HO, Pingree GC, Kirby TJ. Benign mucous membrane pemphigoid. Arch Dermatol 1971; 104: 467-5. membrane pemphigoid. Arch Dermatol 1971;

3 Mondino BJ, Brown SI. Ocular cicatricial pemphigoid. Ophthalmology $1981 ; 88: 95$. 100 .

4 Mondino BJ, Brown SI, Lempert S, Jenkins MS. The acute manifestations of ocular cicatricial pemphigoid. Diagnosis and treatment. Ophthalmology 1979; 86: 543-52.

5 Katz SI. Dapsone. In Fitzpatrick TB, et al, eds. Dermatology in general medicine. London: McGraw-Hill, 1989; Chapter 218: 
6 Person JR, Rogers RS. Bullous pemphigoid responding to sulfapyridine and the sulfones. Arch Dermatol 1977; 113 :

$610-5$

7 Rogers RS, Seehafer JR. Treatment of cicatricial (benign mucous membrane) pemphigoid with dapsone. $\mathcal{f}$ Am Acad Dermatol 1982; 6: 215-23.

8 Venning VA, Millard PR, Woinarowska F. Dapsone as firs line therapy for bullous pemphigoid. Br $\mathcal{F}$ Dermatol 1989 120: 83-92.

9 Wright $P$. The enigma of ocular cicatricial pemphigoid. Trans Ophthalmol Soc UK 1979; 99: 141-5.

10 Duke-Elder S, ed. System of ophthalmology. Vol 8, Part 3. Diseases of the outer eye. London: Kimpton, 1965: 502-19.

11 Leonard JN, Haffenden GP, Ring NP, McMinn RMH, Sidgwick A, Mowbray JF, et al. Linear IgA disease in adults. Brf Dermatol 1982; 107: 301-16.

12 Patten JJ, Cavanagh HD, Allansmith MR. Induced ocular pseudopemphigoid. Am 7 Ophthalmol 1976; 82: 272-6.

13 Hirst LW, Werblin T, Novak M, et al. Drug induced cicatrizing conjunctivitis simulating ocular pemphigoid. Cornea 1982; 1: 121-8

14 Norn MS. Pemphigoid related to epinephrine treatment (letter). Am $\mathcal{F}$ Ophthalmol 1977; 83: 138 .

15 Tauber J, Melamed S, Foster CD. Glaucoma in patients with ocular cicatricial pemphigoid. Ophthalmology 1989; 96 : 33-7.

16 Foster CS. Cicatricial pemphigoid. Trans Am Ophthalmol Soc 1986; 84: 527-663

17 Pouliquen Y, Patey A, Foster CS, Goichot L, Savoldelli M.
Drug-induced cicatricial pemphigoid affecting the conjunctiva light and electron microscopic features. Ophthalmology 1986; 93: 775-83.

18 Frith PA, Venning VA, Woinarowska F, Millard PR, Bron AJ. Conjunctival involvement in cicatricial and bullous pemphigoid: a clinical and immunopathological study. BrF Ophthalmol 1989; 73: 52-6.

19 Mondino BJ, Brown SI, Rabin BS. Autoimmune phenomena of the external eye. Ophthalmology 1978; 85: 801-17.

20 Nieboer C, Roeleveld CG, Kalsbeek GL. Localised chronic pemphigoid. Report of a case, review of the literature and discussion of the relationship with cicatricial pemphigoid. Dermatologica 1978; 156: 24-33.

21 Ahmed AR, Maize JC, Provost TT. Bullous pemphigoid. Clinical and immunological follow-up after successful therapy. Arch Dermatol 1977; 113: 1043-6.

22 Foster CS, Wilson LA, Ekins MB. Immunosuppressive therapy for progressive ocular cicatricial pemphigoid. Ophtherapy for progressi 340 , 3 .

23 Mondino BJ, Brown SI. Immunosuppressive therapy in ocular cicatricial pemphigoid. Am f Ophthalmol 1983; 96: 453-59.

24 Mier PD, Van Den Hurk JJMA. Inhibition of lysosoma enzymes by dapsone. $\mathrm{Br} \mathcal{F}$ Dermatol 1975; 93: 471-2.

25 Stendahl O, Edebo L, Magnusson KE, Tagesson C, Hjerten S The inhibition of polymorphonuclear leukocyte cytotoxicity by dapsone: a possible mechanism in the treatment of dermatitis herpetiformis. $\mathcal{F}$ Clin Invest $1978 ; 62: 214-20$

26 Harvath L, Yancey KB, Katz SI. Selective inhibition of neutrophil chemotaxis by sulfones. Clin Res $1983 ; 31: 571$ A.

\section{FIFTY YEARS AGO}

\section{Syphilis}

War brings many horrors in its train; not the least of these is an increase in syphilis.

- I indicated at the outset that syphilis had shown a definite annual decline in the years preceding the present war. I regret that the number of new acute cases is now beginning to show an alarming increase; this will not be seen in ophthalmology until later on, but unless the acute cases are properly treated it will surely occur, it may be not for ten or fifteen years, when the congenital syphilitic children reach puberty or the half treated cases arrive with lesions of the central nervous system.

Brf Ophthalmol 1942; 26: 23. 